\title{
Front Matter: Volume 8085
}

, "Front Matter: Volume 8085," Proc. SPIE 8085, Videometrics, Range Imaging, and Applications XI, 808501 (7 July 2011); doi: 10.1117/12.902862

SPIE. Event: SPIE Optical Metrology, 2011, Munich, Germany 


\section{PROCEEDINGS OF SPIE}

\section{Videometrics, Range Imaging, and Applications XI}

Fabio Remondino

Mark R. Shortis

Editors

25-26 May 2011

Munich, Germany

Sponsored and Published by

SPIE 
The papers included in this volume were part of the technical conference cited on the cover and title page. Papers were selected and subject to review by the editors and conference program committee. Some conference presentations may not be available for publication. The papers published in these proceedings reflect the work and thoughts of the authors and are published herein as submitted. The publisher is not responsible for the validity of the information or for any outcomes resulting from reliance thereon.

Please use the following format to cite material from this book:

Author(s), "Title of Paper," in Videometrics, Range Imaging, and Applications XI, edited by Fabio Remondino, Mark R. Shortis, Proceedings of SPIE Vol. 8085 (SPIE, Bellingham, WA, 2011) Article CID Number.

ISSN 0277-786X

ISBN 9780819486813

Published by

SPIE

P.O. Box 10, Bellingham, Washington 98227-0010 USA

Telephone +1 3606763290 (Pacific Time) · Fax +1 3606471445

SPIE.org

Copyright (C) 2011, Society of Photo-Optical Instrumentation Engineers

Copying of material in this book for internal or personal use, or for the internal or personal use of specific clients, beyond the fair use provisions granted by the U.S. Copyright Law is authorized by SPIE subject to payment of copying fees. The Transactional Reporting Service base fee for this volume is $\$ 18.00$ per article (or portion thereof), which should be paid directly to the Copyright Clearance Center (CCC), 222 Rosewood Drive, Danvers, MA 01923. Payment may also be made electronically through CCC Online at copyright.com. Other copying for republication, resale, advertising or promotion, or any form of systematic or multiple reproduction of any material in this book is prohibited except with permission in writing from the publisher. The CCC fee code is 0277-786X/11/ \$18.00.

Printed in the United States of America.

Publication of record for individual papers is online in the SPIE Digital Library.

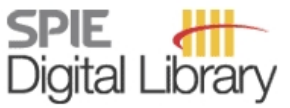

SPIEDigitalLibrary.org

Paper Numbering: Proceedings of SPIE follow an e-First publication model, with papers published first online and then in print and on CD-ROM. Papers are published as they are submitted and meet publication criteria. A unique, consistent, permanent citation identifier (CID) number is assigned to each article at the time of the first publication. Utilization of CIDs allows articles to be fully citable as soon as they are published online, and connects the same identifier to all online, print, and electronic versions of the publication. SPIE uses a six-digit CID article numbering system in which:

- The first four digits correspond to the SPIE volume number.

- The last two digits indicate publication order within the volume using a Base 36 numbering system employing both numerals and letters. These two-number sets start with 00, 01, 02, 03, 04, $05,06,07,08,09,0 A, 0 B \ldots 0 Z$, followed by 10-1Z, 20-2Z, etc.

The CID number appears on each page of the manuscript. The complete citation is used on the first page, and an abbreviated version on subsequent pages. Numbers in the index correspond to the last two digits of the six-digit CID number. 


\section{Contents}

vii Conference Committee
ix Introduction

\section{SESSION 1 ACCURACY AND PERFORMANCE EVALUATION}

808502 3D imaging: how to achieve highest accuracy (Invited Paper) [8085-01]

T. Luhmann, Jade Univ. of Applied Sciences (Germany)

808503 Practical target location and accuracy indicator in digital close range photogrammetry using consumer grade cameras [8085-02]

G. Moriya, H. Chikatsu, Tokyo Denki Univ. (Japan)

808504 Methodologies for digital 3D acquisition and representation of mosaics [8085-03]

A. M. Manferdini, L. Cipriani, Univ. degli Studi di Bologna (Italy); L. Kniffitz, Museo d'Arte della Città di Ravenna (Italy)

808505 Self-calibration for a camera-projector pair [8085-04]

M. Bevilacqua, G. Di Leo, M. Landi, A. Paolillo, Univ. degli Studi di Salerno (Italy)

808506 A power-saving modulation technique for time-of-flight range imaging sensors [8085-05] R. M. Conroy, A. A. Dorrington, A. D. Payne, R. Künnemeyer, M. J. Cree, The Univ. of Waikato (New Zealand)

808507 Real-time image processing of TOF range images using a reconfigurable processor system [8085-06]

S. Hussmann, F. Knoll, T. Edeler, Fachhochschule Westküste Heide (Germany)

\section{SESSION 2 IMAGE- AND RANGE-BASED MODELLING}

808508 Accurate documentation in cultural heritage by merging TLS and high-resolution photogrammetric data [8085-07]

P. Grussenmeyer, E. Alby, P. Assali, V. Poitevin, J.-F. Hullo, E. Smigiel, The Image Sciences, Computer Sciences and Remote Sensing Lab. (France) and Institut National des Sciences Appliquées de Strasbourg (France)

808509 A parallel point cloud clustering algorithm for subset segmentation and outlier detection [8085-08]

C. Teutsch, E. Trostmann, D. Berndt, Fraunhofer-Institut für Fabrikbetrieb und -automatisierung (Germany)

$8085 \mathrm{OA}$ Integration of range and image data for building reconstruction [8085-09] F. Nex, F. Remondino, Fondazione Bruno Kessler (Italy); F. Rinaudo, Politecnico di Torino (Italy) 
8085 OB Performance analysis of different classification methods for hand gesture recognition using range cameras [8085-10]

H. Lahamy, D. D. Lichti, Univ. of Calgary (Canada)

SESSION 3 ACCURACY, SYSTEM PERFORMANCE AND ORIENTATION ANALYSIS

8085 OC Artefacts for optical surface measurement [8085-11]

S. Robson, Univ. College London (United Kingdom); J.-A. Beraldin, National Research Council Canada (Canada); A. Brownhill, L. MacDonald, Univ. College London (United Kingdom)

8085 OD Illumination waveform optimization for time-of-flight range imaging cameras [8085-12] A. D. Payne, A. A. Dorrington, M. J. Cree, The Univ. of Waikato (New Zealand)

8085 OE A descriptive geometry based method for total and common cameras fields of view optimization [8085-13]

H. Salmane, Y. Ruichek, Lab. Systèmes et Transports, CNRS, Univ. de Technologie de Belfort-Montbéliard (France); L. Khoudour, Lab. LEOST, CNRS, Institut National de Recherche sur les Transports et leur Sécurité (France)

8085 OF Experiences and achievements in automated image sequence orientation for close-range photogrammetric projects [8085-14]

L. Barazzetti, Politecnico di Milano (Italy); G. Forlani, Univ. degli Studi di Parma (Italy);

F. Remondino, Fondazione Bruno Kessler (Italy); R. Roncella, Univ. degli Studi di Parma (Italy); M. Scaioni, Politecnico di Milano (Italy)

$80850 \mathrm{G}$ Geometric investigation of a gaming active device [8085-15]

F. Menna, F. Remondino, Fondazione Bruno Kessler (Italy); R. Battisti, Fondazione Bruno Kessler (Italy) and Univ. degli Studi di Trento (Italy); E. Nocerino, Univ. degli Studi di Napoli Parthenope (Italy)

\section{SESSION 4 3D APPLICATIONS}

$8085 \mathrm{OH} \quad$ Industrial photogrammetry: challenges and opportunities (Invited Paper) [8085-16] W. Bösemann, AICON 3D Systems GmbH (Germany)

8085 Ol Integration of photogrammetry and acoustic emission analysis for assessing concrete structures during loading tests [8085-17]

R. Koschitzki, G. Schacht, D. Schneider, S. Marx, H.-G. Maas, Technische Univ. Dresden (Germany)

$80850 \mathrm{~J}$ Vibration measurement of a model wind turbine using high speed photogrammetry [8085-18]

D. Kalpoe, Technische Univ. Delft (Netherlands); K. Khoshelham, Technische Univ. Delft (Netherlands) and Univ. Twente (Netherlands); B. Gorte, Technische Univ. Delft (Netherlands)

8085 OK Use of 3D range cameras for structural deformation measurement [8085-19]

S. Jamtsho, D. D. Lichti, Univ. of Calgary (Canada) 


\section{SESSION 5 3D MODELLING AND MOTION CAPTURE}

$8085 \mathrm{OL} \quad$ Low-cost human motion capture system for postural analysis onboard ships [8085-20] E. Nocerino, Univ. degli Studi di Napoli Parthenope (Italy) and Univ. degli Studi di Napoli Federico II (Italy); S. Ackermann, S. Del Pizzo, Univ. degli Studi di Napoli Parthenope (Italy);

F. Menna, Univ. degli Studi di Napoli Parthenope (Italy) and Fondazione Bruno Kessler (Italy);

S. Troisi, Univ. degli Studi di Napoli Parthenope (Italy)

8085 OM A greedy multiresolution method for quasi automatic texture mapping [8085-21]

F. Uccheddu, Univ. degli Studi di Firenze (Italy); A. Pelagotti, Istituto Nazionale di Ottica Applicata, CNR (Italy); F. Picchioni, Univ. degli Studi di Firenze (Italy)

8085 ON Shadow correction in high dynamic range images for generating orthophotos [8085-22] H. Suzuki, Aero Asahi Corp. (Japan); H. Chikatsu, Tokyo Denki Univ. (Japan)

808500 An approach for the calibration of a combined RGB-sensor and 3D-camera device [8085-23]

M. Schulze, Technische Univ. Dresden (Germany)

\section{SESSION 6 CALIBRATION AND ORIENTATION ALGORIGTHMS}

$80850 Q$ The comparison of single view calibration methods [8085-25]

J. Heikkinen, K. Inkilä, Aalto Univ. (Finland)

8085 OR Planar metric rectification via parallelograms [8085-26]

L. Barazzetti, Politecnico di Milano (Italy)

8085 OS The calibration of wide-angle lens cameras using perspective and non-perspective projections in the context of real-time tracking applications [8085-27]

J. Willneff, Advanced Realtime Tracking GmbH (Germany); O. Wenisch, SensoMotoric Instruments GmbH (Germany)

8085 OT Practical calibration for consumer grade digital camera with integrated high zooming lens [8085-28]

R. Wakutsu, H. Chikatsu, Tokyo Denki Univ. (Japan)

$8085 \mathrm{OU}$ Calibration of low-cost measurement system by using a consumer digital stereo camera [8085-29]

R. Matsuoka, G. Takahashi, K. Asonuma, Kokusai Kogyo Co., Ltd. (Japan)

\section{POSTER SESSION}

$8085 \mathrm{OV}$ 3D documentation of historical sites and buildings for interdisciplinary works [8085-30] E. Tekdal-Emniyeti, Istanbul Teknik Üniv. (Turkey) and Karlsruher Institut für Technologie (Germany); K.-H. Haefele, J. Isele, Karlsruher Institut für Technologie (Germany); R. N. Celik, Istanbul Teknik Üniv. (Turkey) 
8085 OW Three-dimensional surface topography based on digital fringe projection [8085-31] F. Mohammadi, K. Madanipour, A. H. Rezaie, AmirKabir Univ. of Technology (Iran, Islamic Republic of)

8085 OX Large bulk-yard 3D measurement based on videogrammetry and projected contour aiding [8085-32]

J. Ou, X. Zhang, Y. Yuan, X. Zhu, National Univ. of Defense Technology (China) and Hunan Key Lab. of Videometrics and Vision Navigation (China)

$80850 Z$ Infrared digital holography for 3D display [8085-34]

A. Geltrude, Istituto Nazionale di Ottica, CNR (Italy); M. Locatelli, Istituto Nazionale di Ottica, CNR (Italy) and Lab. Europeo per la Spettroscopia Non Lineare, CNR, Univ. di Firenze (Italy); M. Paturzo, A. Pelagotti, P. Poggi, R. Meucci, P. Ferraro, Istituto Nazionale di Ottica, CNR (Italy)

808510 Robust sharp features infer from point clouds [8085-35]

J. Cao, S. Wushour, Xi'an Jiaotong Univ. (China); X. Yao, N. Li, Baoji Univ. of Arts and Sciences (China); J. Liang, X. Liang, J. Liu, Xi'an Jiaotong Univ. (China)

808511 Longitudinal resolution improving of 3D range imaging lidar through redundant detection and intensity distribution analysis [8085-36]

W. Kong, S. Chen, Y. Zhang, H. Chen, Z. Qiu, Y. Wang, P. Liu, G. Ni, Beijing Institute of Technology (China)

808512 A novel color coding method for structured light 3D measurement [8085-37] J. Huang, Z. Wang, Z. Gao, J. Gao, Xi'an Jiaotong Univ. (China)

808513 Three-dimensional contour reconstruction of push-broom range-gated lidar data: case studies [8085-38]

J. Xu, S. Chen, Y. Zhang, H. Chen, P. Guo, G. Ni, Beijing Institute of Technology (China)

Author Index 


\title{
Conference Committee
}

\author{
Symposium Chairs \\ Wolfgang Osten, Universität Stuttgart (Germany) \\ Małgorzata Kujawińska, Warsaw University of Technology (Poland) \\ Pietro Ferraro, Istituto Nazionale di Ottica Applicata, CNR (Italy)
}

Conference Chairs

Fabio Remondino, Fondazione Bruno Kessler (Italy)

Mark R. Shortis, RMIT University (Australia)

Programme Committee

J. Angelo Beraldin, National Research Council Canada (Canada) Jan Boehm, Universität Stuttgart (Germany)

Werner Bösemann, AICON 3D Systems GmbH (Germany)

Hirofumi Chikatsu, Tokyo Denki University (Japan)

Nicola D'Apuzzo, Homometrica Consulting (Switzerland)

Sabry F. El-Hakim, Carleton University (Canada)

Gabriele Guidi, Politecnico di Milano (Italy)

Jussi Heikkinen, Aalto University School of Science and Technology

(Finland)

Derek D. Lichti, University of Calgary (Canada)

Hans-Gerd Maas, Technische Universität Dresden (Germany)

Jon P. Mills, Newcastle University (United Kingdom)

Norbert Pfeifer, Technische Universität Wien (Austria)

Stuart Robson, University College London (United Kingdom)

David Stoppa, Fondazione Bruno Kessler (Italy)

Session Chairs

1 Accuracy and Performance Evaluation

Mark R. Shortis, RMIT University (Australia)

2 Image- and Range-based Modelling

Fabio Remondino, Fondazione Bruno Kessler (Italy)

3 Accuracy, System Performance and Orientation Analysis

Mark R. Shortis, RMIT University (Australia)

$4 \quad 3 D$ Applications

Fabio Remondino, Fondazione Bruno Kessler (Italy) 
5 3D Modelling and Motion Capture

Mark R. Shortis, RMIT University (Australia)

6 Calibration and Orientation Algorigthms

Fabio Remondino, Fondazione Bruno Kessler (Italy) 


\section{Introduction}

The Videometrics, Range Imaging, and Applications XI conference is the thirteenth in a series commenced in 1991. Under the auspices of SPIE, Sabry ElHakim arranged the first conference on Industrial Vision Metrology, held at Winnipeg in Canada. Based on the success of this first venture into an emerging discipline, the conference was renamed Videometrics and held in conjunction with the SPIE Photonics East group of conferences in Boston and Philadelphia during 1992-1995. Videometrics was then re-located to become part of SPIE Photonics West, held annually in California. The conferences were held once in San Diego in 1997, then twice in San Jose in 1999 and 2001 (given the longer title: Videometric and Optical Methods for 3D Shape Measurement), then moved to Santa Clara in 2003 and moved back to San Jose in 2005 and 2007. More recently, Videometrics became part of Optics + Photonics program track on Image and Signal Processing within the Optical Engineering and Applications conferences in San Diego in 2009.

Throughout all of this period, the attendance from North America has slowly declined, and the participation from Europe and Asia has strengthened. Videometrics, Range Imaging, and Applications XI is certainly representative of this trend, with the majority of authors and presenters from Europe. Accordingly, in 2011 the conference moved to Munich to be part of the SPIE Europe conference on Optical Metrology, co-located with the World of Photonics conference and exhibition. Given the history of Videometrics this home might be only temporary accommodation, but certainly the general theme of Optical Metrology resonates very well with Videometrics.

Indeed, for more than two decades the Videometrics conference series has been providing a unique forum for optical metrology, computer vision, image processing and photogrammetry researchers and practitioners to present the latest advances in precise 3D measurement and modeling from imaging and range sensors. This conference was originally focused on the metric performance of sensors and algorithms to produce the most accurate and reliable geometric measurements and models. Topics such as sensor calibration, performance evaluation and accurate object reconstruction were predominant. This has now been expanded to encompass all phases of 3D optical imaging, range imaging and modeling of real scenes, including automation of data collection and processing, improving the visual quality and realism, visualization, animation and data management for real-time manipulation. This is in response to the sustained increase in interest in 3D imaging and modeling technology, and the increased demand of these models in applications such as rapid product development, virtual museums, documentation of monuments and architecture for cultural heritage, marketing and tourism, human body modeling, medicine, and exploration of remote and hazardous sites, to name just a few. 
In 2011 Videometrics, Range Imaging, and Applications XI demonstrates the continuing broad interest in 3D optical imaging, with sessions encompassing all aspects of the field, from performance evaluation to 3D modeling and applications. The two invited speakers reinforce this span of interest, Prof. Thomas Luhmann from Jade University of Applied Sciences presenting on accuracy considerations and Dr. Werner Boesemann from AICON 3D Systems presenting the state of the art in 3D applications. Whilst Videometrics embraces new technologies such as enhancing time of flight range imaging and developing new techniques such as in the area of fusion of range and image data, the classical problems of calibration and standards are still well represented. Videometrics contains something of interest for all practitioners involved in 3D optical imaging.

The Chairs recognise and acknowledge with gratitude the efforts of the Conference Committee members, the authors, presenters and audience, and especially the invited speakers, in maintaining the high level of interest in Videometrics. We acknowledge and appreciate the contribution to the success of the conference from everyone involved in Videometrics.

Mark R. Shortis Fabio Remondino 